\title{
Analisis Yuridis terhadap Kasus Gugatan Perbuatan Melawan Hukum atas Ketidakabsahan Peralihan Hak Milik Benda Bergerak (Studi Kasus Putusan Mahkamah Agung Nomor 1081/K/PDT/2018)
}

\author{
Fathalya Laksana网 \\ Program Studi Ilmu Hukum, Universitas Padjadjaran \\ Email: fathalyal@yahoo.com
}

\begin{abstract}
The legal requirements are regulated in Article 1320 of the Civil Code (KUHPerdata). If the valid conditions of the promise are not fulfilled, then the law that results is that the agreement can be canceled or null and void. In the Court's practice contained in the Supreme Decision Number 1081K / PDT / 2018, there was a sale and purchase agreement between the Plaintiffs husband and the Defendant, the sale and purchase agreement was made by the Plaintiff's partner without the consent of the Plaintiff as his legal wife. Supreme Court Decision No. 1081K / PDT / 2018 stated that the sale and purchase agreement was invalid and null and void. Apart from that, in its decision, the Defendant's UN Supreme Court had committed an illegal act. The research method used is a normative juridical approach using secondary data obtained from literature studies, namely statutory regulations, legal theories, and the opinions of leading legal scholars. This research uses descriptive analytical research specifications that describe the regulations that are in accordance with legal theories that oversee the implementation practices of the problems under study. The data analysis method used is qualitative normative method. Based on the research results, it can be denied that the sale and purchase agreement in the Supreme Court Decision Number 1081K / PDT / 2018 is not legally valid. The agreement does not fulfill the validity requirements of the agreement in Article 1320 of the Civil Code, namely halal skills and causes because it violates Article 36 paragraph (2) of the Marriage Law No. 1 of 1974 resulting in the sale and purchase agreement to be null and void.
\end{abstract}

Keywords: Buying and Selling, Acts against the Law, Agreement, Marriage, Collective Property

\section{Abstrak}

Syarat-syarat sahnya suatu perjanjian diatur di dalam Pasal 1320 Kitab Undang-Undang Hukum Perdata (KUHPerdata). Apabila syarat-syarat sahnya perjanjian tidak terpenuhi, maka akibat hukum yang ditimbulkan adalah perjanjian tersebut dapat dibatalkan atau batal demi hukum. Dalam praktek sebagaimana yang terdapat pada Putusan Mahkamah Agung Nomor 1081K/PDT/2018, terjadi perjanjian jual beli antara suami Penggugat dengan Tergugat, perjanjian jual beli tersebut dibuat oleh suami Penggugat dengan tanpa persetujuan Penggugat selaku isteri sahnya. Putusan Mahkamah Agung Nomor 1081K/PDT/2018 menyatakan bahwa perjanjian jual beli tersebut tidak sah dan batal demi hukum. Selain itu dalam putusannya Mahkamah Agung menyatakan Tergugat telah melakukan perbuatan melawan hukum. Metode penelitian yang digunakan adalah metode pendekatan yuridis normatif dengan menggunakan data sekunder yang diperoleh dari studi kepustakaan, yaitu peraturan perundang-undangan, teori-teori hukum, dan pendapat para sarjana hukum terkemuka. Penelitian menggunakan spesifikasi penelitian deskriptif analitis yaitu menggambarkan peraturan perundangundangan yang berlaku dengan teori-teori hukum dikaitkan dengan praktik pelaksanaannya yang menyangkut permasalahan yang diteliti. Metode analisis data yang digunakan adalah metode normatif kualitatif. Berdasarkan hasil penelitian, dapat disimpulkan bahwa perjanjian jual beli dalam Putusan Mahkamah Agung Nomor 1081K/PDT/2018 tidak sah secara hukum. Perjanjian tersebut tidak memenuhi syarat sahnya perjanjian di dalam Pasal 1320 KUHPerdata yaitu kecapakan dan kausa yang halal karena melanggar Pasal 36 ayat (2) Undang-Undang Perkawinan No. 1 Tahun 1974 sehingga mengakibatkan perjanjian jual beli tersebut menjadi batal demi hukum.

Kata Kunci: Jual Beli, Perbuatan Melawan Hukum, Perjanjian, Perkawinan, Harta Bersama 
Kosmik Hukum Vol. 19 No. 2 (2019): 14-23

E-ISSN: 2655-9242 | P-ISSN: 1411-9781

DOI: $10.30595 /$ kosmikhukum.v20i1.6324

\section{Pendahuluan}

Masalah yang sering sekali timbul akibat jual beli yaitu kurangnya akta jual beli atau bukti lainnya yang dimiliki oleh pembeli dari penjual sebagai tanda bahwa telah terjadi proses peralihan hak milik dengan cara jual beli, yang kemudian memunculkan sengketa antara keluarga pembeli dengan penjual, meskipun untuk jual beli benda bergerak dapat dilakukan secara lisan dengan ketentuan sudah ada perjanjian antara kedua belah pihak untuk mengikatkan dirinya. Hal tersebut ditegaskan dalam Pasal 1457 KUH Perdata tentang jual beli yang menyatakan bahwa jual beli adalah suatu perjanjian, dengan mana pihak yang satu mengikatkan dirinya untuk menyerahkan suatu kebendaan, dan pihak yang lain untuk membayar harga yang telah dijanjikan. Namun hal tersebut berbeda jika objek yang diperjualbelikan merupakan harta bersama dalam perkawinan, karena jual beli yang dilakukan harus sesuai dengan syarat-syarat yang terdapat didalam UU Perkawinan tentang harta benda dalam perkawinan.

Seperti halnya di Indonesia banyak terjadi kasus ketidakabsahan proses peralihan hak milik dengan cara jual beli, yang mana objek jual beli merupakan harta bersama dalam perkawinan. Hal tersebut terjadi karena proses jual beli tidak sesuai dengan syarat-syarat yang terdapat didalam UU Perkawinan tentang harta benda dalam perkawinan. Proses jual beli yang tidak sah tersebut dikarenakan adanya sikap saling percaya dan mengutamakan prinsipprinsip saling kekeluargaan. Namun, dimasa sekarang penyebab utama masyarakat tidak membuat akta jual beli ialah karena kebanyakan dari masyarakat memandang bahwa membuat akta jual beli itu memerlukan waktu yang lama, membutuhkan dana yang besar, dan repot dalam pengurusannya. Banyak dari masyarakat khususnya pembeli, melakukan proses balik nama terhadap objek yang diperjualbelikan tanpa adanya akta yang jelas tentang jual beli tersebut. Hal tersebut memunculkan sengketa antara keluarga pembeli dan penjual. Karena ketidakjelasan proses jual beli tersebut memunculkan tanda tanya, apakah proses balik nama yang dilakukan oleh pembeli terhadap objek jual beli tanpa adanya akta yang jelas, dapat dikategorikan sebagai perbuatan melawan hukum. Terlebih jika objek jual beli merupakan benda bergerak yang berasal dari harta bersama dalam perkawinan.

Berdasarkan latar belakang tersebut, Studi Kasus ini akan membahas mengenai Kasus Gugatan Perbuatan Melawan Hukum dimana terjadi perebutan hak milik benda bergerak yaitu berupa 1 (satu) unit kendaraan roda empat KB. 1435 YL Merk Toyota Warna Silver Metalik, Tipe Model: Mini Bus, Tahun Pembuatan 2008, Nomor Rangka: MHFXW3G184038407 Nomor Mesin: 1 TR- 6525894 dahulu atas M. Dasuki alias H. Muhammad Dasuki (almarhum) sekarang atas nama Hj. Zubaidah.

\section{Metodologi Penelitian}

Metode penelitian yang digunakan adalah metode pendekatan yuridis normatif dengan menggunakan data sekunder yang diperoleh dari studi kepustakaan, yaitu peraturan perundang-undangan, teori-teori hukum, dan pendapat para sarjana hukum terkemuka. Penelitian menggunakan spesifikasi penelitian deskriptif analitis yaitu menggambarkan peraturan perundang-undangan yang berlaku dengan teori-teori hukum dikaitkan dengan 
praktik pelaksanaannya yang menyangkut permasalahan yang diteliti. Metode analisis data yang digunakan adalah metode normatif kualitatif.

\section{Hasil dan Pembahasan}

\section{Keabsahan Jual Beli ditinjau dari Pasal 1320 KUH Perdata tentang Syarat Sahnya Perjanjian}

Perjanjian diatur dalam Pasal 1313 Kitab Undang-Undang Hukum Perdata, yang menyatakan bahwa perjanjian adalah suatu perbuatan hukum dengan mana dua orang atau lebih mengikatkan dirinya atau saling mengikatkan dirinya terhadap satu orang atau lebih. Menurut Kitab Undang-Undang Hukum Perdata, suatu perjanjian pada hakikatnya telah terjadi dengan adanya sepakat (Consensus) dari kedua belah pihak dan mengikat mereka yang membuatnya, layaknya mengikatnya suatu undang-undang. Pengertian dari perikatan, merupakan terjemahan dari istilah Belanda "Verbintenis".1 Dalam hal ini perikatan tidak hadir begitu saja, dengan kata lain ada sesuatu atau persetujuan tertentu yang melahirkan suatu perikatan. Dalam Pasal 1233 Kitab Undang-Undang Hukum Perdata, menyatakan bahwa perikatan dapat lahir dari suatu persetujuan (perjanjian) dan undang-undang.

Hubungan antara perikatan dan perjanjian adalah bahwa perjanjian itu menerbitkan perikatan. Perjanjian adalah sumber perikatan, di sampingnya sumber-sumber lain. Suatu perjanjian juga dinamakan persetujuan, karena dua pihak itu setuju melakukan sesuatu. Dapat dikatakan bahwa dua perkataan (perjanjian dan persetujuan) itu adalah sama artinya.

Menurut Pasal 1457 KUH Perdata, jual beli adalah suatu perjanjian atau persetujuan atau kontrak di mana satu pihak mengikatkan diri untuk menyerahkan suatu kebendaan dan pihak lainnya yang mengikatkan dirinya untuk membayar harga yang telah dijanjikan. R. Wirjono Prodjodikoro menyebutkan perkataan jual beli menunjukkan bahwa dari satu pihak perbuatan dinamakan penjual, sedangkan dari pihak yang lain dinamakan pembeli.2 Istilah yang mencakup dua perbuatan yang bertimbal balik ini adalah sesuai dengan istilah Belanda koop en ver koop yang satu 'verkoop' (menjual) sedangkan yang lainnya 'koop' (membeli).

Perjanjian jual beli akan menjadi sah apabila memenuhi Pasal 1320 KUHPerdata yang mengatur bahwa perjanjian harus memenuhi syarat sahnya perjanjian, yaitu kata sepakat, kecakapan, suatu hal tertentu dan suatu sebab yang halal. Apabila dipenuhi empat syarat sahnya perjanjian tersebut, maka perjanjian jual beli tersebut sah dan mengikat bagi para pihak. Namun sebaliknya jika perjanjian jual beli tidak memenuhi Pasal 1320 KUHPerdata tentang syarat sahnya perjanjian, maka perjanjian jual beli tersebut menjadi batal.3

Di Indonesia terdapat banyak kasus mengenai perjanjian jual beli dalam lapangan harta kekayaan bersama, perjanjian jual beli tersebut tidak didasarkan atas persetujuan suami atau isteri yang kita ketahui bahwa jika suami atau isteri akan melakukan perbuatan hukum terhadap harta kekayaan bersama harus berdasarkan persetujuan kedua belah pihak jika tidak maka perbuatan hukum tersebut menjadi batal.

\footnotetext{
R. Setiawan, “Pokok-pokok Hukum Perikatan”, Bina Cipta, Bandung, 2007, hlm.49.

R. Wirjono Prodjodikoro., Op.Cit, hlm. 22.

Muhammad Billah Yudahian, “Perjanjian Jual Beli Secara Online Melalui Rekening Bersama Pada Forum Jual Beli
} Kaskus", Universitas Hasanuddin : Makassar. 
Kosmik Hukum Vol. 19 No. 2 (2019): 14-23

E-ISSN: 2655-9242 | P-ISSN: 1411-9781

DOI: 10.30595/kosmikhukum.v20i1.6324

Seperti pada Kasus Putusan Mahkamah Agung Nomor 1081K/PDT/2018 yang merupakan kasus gugatan perbuatan melawan hukum antara Penggugat Sainah dengan Tergugat Zubaidah. Penggugat Sainah mengajukan gugatan tersebut dengan dalil bahwa Tergugat telah melakukan perbuatan melawan hukum karena telah membalik nama 1 unit kendaraan roda empat KB. 1435 YL Merk Toyota Warna Silver Metalik, Tipe Model: Mini Bus, Tahun Pembuatan 2008, Nomor Rangka: MHFXW3G184038407 Nomor Mesin: 1 TR-6525894 menjadi atas nama Tergugat Zubaidah.

Kendaraan roda empat tersebut diketahui merupakan harta bersama Penggugat Sainah dengan suaminya H. Muhammad Dasuki. H. Muhammad Dasuki pada kenyataannya telah menjual kendaraan roda empat tersebut kepada Tergugat Zubaidah, tetapi proses jual beli yang dilakukan oleh H. Muhammad Dasuki kepada Tergugat Zubaidah dilakukan secara lisan dengan alat bukti pembayaran berupa kwitansi tanpa tempat dan tanggal. Proses peralihan hak dari H. Muhammad Dasuki kepada Tergugat Zubaidah, dilakukan oleh H. Muhammad Dasuki sendiri sebagai pemilik mobil, dan proses balik nama pada saat H. Muhammad Dasuki masih hidup dilakukan sendiri olehnya di kantor samsat sampai terbitnya BPKB atas nama Tergugat Zubaidah. Namun jual beli yang dilakukan oleh H. Muhammad Dasuki atas kendaraan roda empat tersebut, yang merupakan harta bersama antara H. Muhammad Dasuki dengan isterinya Sainah tidak diketahui dan disetujui oleh Sainah selaku isteri sahnya.

Mahkamah Agung menguatkan Putusan Pengadilan Tingkat Pertama dan Tingkat Banding, yang dalam Putusannya mengabulkan sebagian gugatan dari Penggugat Sainah yang menyatakan bahwa jual beli yang dilakukan oleh suami Penggugat Sainah dengan Tergugat Zubaidah adalah Batal Demi Hukum. Menyatakan menurut hukum bahwa Tergugat Zubaidah telah melakukan perbuatan melawan hukum, karena telah melakukan proses balik nama yang tidak sah terhadap satu unit kendaraan roda empat KB. 1435 YL Merk Toyota Warna Silver Metalik, Tipe Model: Mini Bus, Tahun Pembuatan 2008, Nomor Rangka: MHFXW3G184038407 Nomor Mesin: 1 TR-6525894.

Berdasarkan Putusan Mahkamah Agung dalam perkara Kasus Nomor 1081K/PDT/2018 yang menyatakan bahwa jual beli yang dilakukan oleh suami Penggugat Sainah dengan Tergugat Zubaidah adalah Batal Demi Hukum, dengan pertimbangan: a) Bahwa objek sengketa berupa 1 (satu) unit mobil kijang Innova Nomor Polisi KB 1435 YL terbukti merupakan harta bersama antara Penggugat dengan almarhum suaminya, M. Dasuki alias H. Muhammad Dasuki; b) Bahwa Penggugat selaku istri almarhum M. Dasuki alias H. Muhammad Dasuki adalah ahli waris yang berhak atas harta bersama tersebut.

Pertimbangan Hakim tersebut maka dapat penulis analisis mengenai keabsahan jual beli antara suami Penggugat Sainah dengan Tergugat Zubaidah ditinjau dari syarat sahnya perjanjian dalam Pasal 1320 KUHPerdata yang menetapkan 4 (empat) syarat, yaitu4 :

\section{a. Kesepakatan}

Kesepakatan/kesetujuan para pihak mengenai pokok-pokok isi perjanjian yang dikehendaki oleh pihak yang satu dan juga dikehendaki oleh pihak lainya. Persetujuan tersebut sudah final, tidak lagi dalam proses perundingan. Pada Kasus Putusan Mahkamah Agung No. A. Qirom Syamsudin Meliala, “Pokok-Pokok Hukum Perjanjian Beserta Perkembangannya”, Yogyakarta, Liberty,
2010, hlm. 9 
1081K/PDT/2018, pihak-pihak yang mengadakan perjanjian jual beli adalah suami Penggugat H. Muhammad Dasuki dengan Tergugat Zubaidah. Perjanjian jual beli tersebut telah memenuhi unsur sepakat, dengan adanya kwitansi jual beli yang dibuat oleh suami Penggugat dengan Tergugat Zubaidah membuktikan telah ada kesepakatan mengenai harga dan barang dalam perjanjian jual beli yang dilakukan oleh suami Penggugat dengan Tergugat Zubaidah.

\section{b. Cakap dan Berwenang}

Undang-undang menentukan bahwa untuk dapat bertindak dalam hukum, seseorang harus telah cakap dan berwenang. Seseorang dapat dikatakan telah cakap dan berwenang harus memenuhi syarat-syarat yang ditentukan oleh undang-undang yaitu telah dewasa, sehat pikirannya (tidak dibawah pengampuan) serta tidak bersuami bagi wanita.

Kecakapan bertindak merupakan salah satu cakap hukum yaitu kemampuan untuk melakukan perbuatan hukum. Perbuatan hukum adalah perbuatan yang akan menimbulkan akibat hukum. Orang yang dikatakan cakap melakukan perbuatan hukum adalah orang yang sudah dewasa artinya sudah mencapai umur 21 tahun atau sudah kawin walaupun belum berumur 21 tahun.5 Orang yang tidak cakap untuk melakukan perbuatan hukum adalah:

1. Orang-orang yang belum dewasa;

2. Mereka yang ditaruh di bawah pengampunan; dan

3. Orang-orang perempuan, dalam hal-hal yang ditetapkan oleh undangundang, dan pada umumnya semua orang kepada siapa undang-undang telah melarang membuat perjanjian-perjanjian tertentu. (ketentuan ini telah dicabut oleh Surat Edaran Mahkamah Agung).

Pada Kasus Putusan Mahkamah Agung No.1081/K/PDT/2018 jika ditinjau dari cakapnya seseorang untuk mengadakan perjanjian, suami penggugat cakap dalam mengadakan perjanjian dilihat dari umur suami Penggugat yang telah lebih mencapai umur 21 tahun dan statusnya yang sudah menikah dengan Penggugat Sainah memperkuat bahwa suami Penggugat telah cakap untuk melakukan suatu perbuatan hukum. Selain itu suami Penggugat tidak sedang ditaruh di bawah pengampuan.

Cakap (bekwaan) adalah kriteria umum yang dihubungkan dengan keadaan diri seseorang, Berwenang (bevoegd) merupakan kriteria khusus yang dihubungkan dengan suatu perbuatan atau tindakan tertentu. Seorang yang cakap belum tentu berwenang, tapi seorang yang berwenang sudah pasti cakap.6

Kasus Putusan Mahkamah Agung No.1081/K/PDT/2018 diketahui suami Penggugat tidak berwenang untuk melakukan perjanjian jual beli dengan Tergugat Zubaidah karena suami Penggugat tidak mendapatkan persetujuan Sainah selaku isteri sahnya untuk melakukan perjanjian jual beli dengan Tergugat Zubaidah. Hal tersebut melanggar Pasal 36 ayat (1) Undang-Undang Perkawinan No. 1 Tahun 1974 yang menyatakan perbuatan hukum pada lapangan harta kekayaan bersama harus berdasarkan persetujuan kedua belah pihak. Dengan demikian suami Penggugat merupakan seseorang yang cakap tetapi tidak berwenang melakukan perbuatan hukum, maka syarat cakap (Bekwaan) dan berwenang (Bevoegd) tidak terpenuhi.

R.Subekti dan R.Tjitrosudibio. “Kitab Undang-undang Hukum Perdata”. Jakarta, Pradnya Paramita, Cetakan ke-37. 2006,hlm. 341.

6 Abdulkadir Muhammad., “Hukum Perikatan”, Alumni, Bandung, 2002, hlm.148 
Kosmik Hukum Vol. 19 No. 2 (2019): 14-23

E-ISSN: 2655-9242 | P-ISSN: 1411-9781

DOI: 10.30595/kosmikhukum.v20i1.6324

c. Objek atau Hal tertentu

Suatu hal tertentu maksudnya adalah paling tidak, macam atau jenis benda dalam perjanjian sudah ditentukan, pengertian objek disini ialah apa yang diwajibkan kepada debitur dan apa yang menjadi hak dari kreditur. Pada kasus Putusan Mahkamah Agung No. 1081/K/PDT/2018 macam atau jenis benda dalam perjanjian sudah ditentukan yaitu berupa satu unit kendaraan roda empat KB. 1435 YL Merk Toyota Warna Silver Metalik, Tipe Model: Mini Bus, Tahun Pembuatan 2008, Nomor Rangka: MHFXW3G184038407 Nomor Mesin: 1 TR6525894.

d. Suatu Sebab yang Halal

Suatu sebab yang halal ialah apa yang menjadi isi dari perjanjian itu tidak bertentangan dengan undang-undang, kesusilaan, dan ketertiban umum.

Kasus Putusan Mahkamah Agung No. 1081/K/PDT/2018 bertentangan dengan Pasal 36 ayat (1) Undang-Undang Perkawinan No. 1 Tahun 1974 tentang Harta Benda dalam Perkawinan yang menyatakan mengenai harta bersama suami atau isteri dapat bertindak atas perjanjian kedua belah pihak.7 Karena didalam kasus tersebut suami Penggugat dalam melakukan perjanjian jual beli dengan Tergugat Zubaidah tidak berdasarkan atas izin sang isteri/Penggugat Sainah, maka dari itu perjanjian tersebut bertentangan dengan UndangUndang Perkawinan No. 1 Tahun 1974.

Keempat syarat tersebut dapat dibagi dalam 2 (dua) kelompok, yaitus :

1. Syarat Subjektif

Syarat subjektif yaitu suatu syarat yang menyangkut subjek-subjek perjanjian itu, dengan kata lain syarat-syarat yang harus dipenuhi adalah sepakat mereka mengikatkan dirinya dan kecakapan pihak yang membuat perjanjian. Apabila syarat kesatu dan kedua tidak dipenuhi, maka akibat hukumnya adalah perjanjian itu menjadi dapat dibatalkan.

Pada Kasus Putusan Mahkamah Agung No. 1081K/PDT/2018 dilihat dari hasil analisa terhadap Pasal 1320 KUH Perdata mengenai syarat sahnya perjanjian, dapat disimpulkan bahwa kasus tersebut tidak melanggar syarat subjektif syarat sahnya perjanjian yang terdapat dalam Pasal 1320 KUHPerdata, yaitu tidak melanggar syarat mengenai kesepakatan karena suami Penggugat dengan Tergugat sudah sepakat untuk melakukan perjanjian jual beli yang dibuktikan dengan adanya kwitansi jual beli meskipun tanpa tempat dan tanggal dan tidak melanggar syarat mengenai kecakapan karena suami Penggugat telah cakap dalam melakukan perbuatan hukum, dengan statusnya yang sudah menikah dengan Penggugat Sainah.

\section{Syarat Objektif}

Mochamad Djais,“Hukum Harta Kekayaan Dalam Perkawinan”, Fakultas Hukum Universitas Diponegoro : Semarang, 2003,hlm. 34 .

$8 \quad$ Ibid, hlm. 11 
Syarat objektif adalah syarat yang menyangkut objek perjanjian itu, meliputi suatu hal tertentu dan suatu sebab yang halal. Syarat yang ketiga dan syarat yang keempat merupakan syarat objektif, syarat objektif tidak dipenuhi, maka perjanjian itu akibatnya batal demi hukum.9

Pada Kasus Putusan Mahkamah Agung No. 1081K/PDT/2018 dilihat dari hasil analisa terhadap Pasal $1320 \mathrm{KUH}$ Perdata mengenai syarat sahnya perjanjian, dapat disimpulkan bahwa kasus tersebut telah melanggar syarat objektif karena tidak memenuhi syarat suatu sebab yang halal dalam perjanjian.

Pada hakekatnya Kasus Putusan Mahkamah Agung Nomor 1081K/PDT/2018 merupakan kasus yang membahas mengenai perjanjian jual beli. Jual beli diatur secara khusus di dalam Pasal 1457 KUH Perdata sampai dengan Pasal 1540 KUHPerdata. Penulis menganalisis bagaimana keabsahan jual beli yang dilakukan suami Penggugat dengan Tergugat, dikaitkan dengan Pasal mengenai jual beli yang diatur di dalam KUHPerdata.

Pada kasus Putusan Mahkamah Agung Nomor 1081K/PDT/2018 diketahui bahwa suami Penggugat telah mengikatkan dirinya kepada Tergugat Zubaidah dalam perjanjian jual beli, untuk menyerahkan suatu kebendaan yang berupa kendaraan roda empat tersebut dan pihak lain yang mana adalah Tergugat Zubaidah untuk membayar harga yang telah dijanjikan. Tergugat Zubaidah diketahui telah membayar harga kendaraan roda empat tersebut, yang dibuktikan dengan adanya alat bukti pembayaran berupa kwitansi tanpa tempat dan tanggal.

Menurut Pasal 1458 KUH Perdata, jual beli itu dianggap telah terjadi antara kedua belah pihak, seketika setelahnya orang-orang ini mencapai sepakat tentang kebendaan tersebut dan harganya meskipun kebendaan itu belum diserahkan maupun harganya belum dibayar. Artinya jika dikaitkan dengan Kasus Putusan Mahkamah Agung Nomor 1081K/PDT/2018, jual beli antara suami Penggugat dengan Tergugat Zubaidah dianggap telah terjadi karena telah terjadi kesepakatan diantara para pihak, hal itu diperkuat dengan adanya kesepakatan harga di dalam kwitansi pembayaran kendaraan roda empat tersebut meskipun kesepakatan terjadi secara lisan.

Selain itu menurut Pasal 1459 KUH Perdata menyebutkan hak milik atas barang yang dijual tidaklah berpindah kepada si pembeli selama penyerahannya belum dilakukan menurut Pasal 612,613, dan 616.10

Dalam Kasus Putusan Mahkamah Agung Nomor 1081K/PDT/2018 penyerahan barang telah dilakukan oleh suami Penggugat Sainah kepada Tergugat Zubaidah pada saat pendaftaran balik nama BРKB. Karena benda yang diperjualbelikan berupa benda bergerak bertubuh penyerahan benda tersebut harus dilakukan sesuai dengan Pasal 612 KUH Perdata, Pasal 612 ayat (1) KUH Perdata menyebutkan penyerahan kebendaan bergerak, terkecuali yang tak bertubuh dilakukan dengan penyerahan yang nyata akan kebendaan itu oleh atau atas nama pemilik, atau dengan penyerahan kunci-kunci dari bangunan, dalam mana kebendaan itu berada.11

\footnotetext{
Ahmad Miru, “Hukum Perjanjian \& Perancangan Perjanjian”.,PT. Raja Grafindo Persada : Jakarta, 2008,hlm.31 Kartini Muljadi dan Gunawan Widjaja, "Perikatan yang Lahir dari Perjanjian”, Rajawali : Jakarta, 2010, hlm. 7-8

Subekti dan Tjitrosudibio, “Kitab Undang-Undang Hukum Perdata”, Jakarta: PT. Pradnya Paramita, 2008, hlm. 338.
} 
Kosmik Hukum Vol. 19 No. 2 (2019): 14-23

E-ISSN: 2655-9242 | P-ISSN: 1411-9781

DOI: 10.30595/kosmikhukum.v20i1.6324

Artinya kasus tersebut telah memenuhi Pasal 1459 KUH Perdata dan Pasal 612 KUH Perdata, yang mana penyerahan tersebut telah dilakukan sesuai dengan ketentuan di dalam undang-undang, penyerahan tersebut artinya adalah sah secara hukum karena suami Penggugat Sainah telah menyerahkan kendaraan roda empat tersebut kepada Tergugat Zubaidah selaku pembeli kendaraan roda empat, secara nyata dan dibuktikan dengan pendaftaran balik nama BPKB di samsat menjadi atas nama Zubaidah dan dengan adanya kwitansi jual beli kendaraan roda empat. Perjanjian jual beli untuk benda bergerak bertubuh dibutuhkan tempat penyerahan secara nyata dan bukti penjualan, meskipun perjanjian dilakukan secara lisan.

Hal yang menjadi pokok persoalan adalah sahnya perjanjian jual beli selain harus memenuhi pasal mengenai jual beli di dalam KUHPerdata juga harus memenuhi Pasal 1320 KUHPerdata tentang syarat sahnya perjanjian. Di dalam analisis penulis diatas mengenai syarat sahnya perjanjian dikaitkan dengan kasus Putusan Mahkamah Agung Nomor 1081K/PDT/2018, kasus tersebut melanggar syarat objektif dari Pasal 1320 KUHPerdata tentang syarat sahnya perjanjian yaitu suatu sebab yang halal. Di dalam Kasus Putusan Mahkamah Agung No. 1081/K/PDT/2018 bertentangan dengan Pasal 36 ayat (1) UndangUndang Perkawinan No. 1 Tahun 1974 tentang Harta Benda dalam Perkawinan yang menyatakan mengenai harta bersama suami atau isteri dapat bertindak atas perjanjian kedua belah pihak.12 Diketahui didalam kasus tersebut suami Penggugat dalam melakukan perjanjian jual beli dengan Tergugat Zubaidah tidak berdasarkan atas izin sang isteri/Penggugat Sainah, maka dari itu perjanjian tersebut bertentangan dengan Undang-Undang Perkawinan No. 1 Tahun 1974.

Kesimpulan yang di dapat dari analisis kasus Putusan Mahkamah Agung Nomor 1081K/PDT/2018 adalah meskipun dalam perjanjian jual beli telah memenuhi pasal khusus mengenai jual beli di dalam KUHPerdata, tidak menghilangkan Pasal 1320 KUHPerdata mengenai syarat sahnya perjanjian. Karena yang menjadi tolak ukur sahnya suatu perjanjian ada di dalam Pasal 1320 KUHPerdata mengenai syarat sahnya perjanjian. Di dalam kasus Putusan Mahkamah Agung Nomor 1081K/PDT/2018 suami Penggugat tidak mendapat persetujuan dari Penggugat Sainah selaku isteri sah dari suami Penggugat untuk membuat perjanjian jual beli dengan tergugat Zubaidah. Maka secara otomatis suami Penggugat melanggar Pasal 36 ayat (1) Undang-Undang Perkawinan No. 1 Tahun 1974 tentang Harta Benda dalam Perkawinan yang menyatakan mengenai harta bersama suami atau isteri dapat bertindak atas perjanjian kedua belah pihak. Perjanjian jual beli yang dilakukan oleh suami Penggugat dengan Tergugat Zubaidah menjadi batal demi hukum karena melanggar syarat sahnya perjanjian yaitu kausa yang halal.

\section{Unsur-Unsur Perbuatan Melawan Hukum dalam Kasus Putusan Mahkamah Agung No. 1081K/PDT/2018}

Di Indonesia banyak terjadi kasus mengenai Perbuatan Melawan Hukum yang dilakukan oleh badan hukum maupun perseorangan, salah satunya adalah Kasus Putusan Mahkamah Agung Nomor 1081K/PDT/2018. Kasus Putusan Mahkamah Agung No. 1081K/PDT/2018 menyebutkan bahwa telah terjadi perjanjian jual beli antara suami Penggugat

12 Mochamad Djais, "Hukum Harta Kekayaan Dalam Perkawinan”, Fakultas Hukum Universitas Diponegoro : Semarang, 2003,hlm. 34 . 
dengan Tergugat Zubaidah, perjanjian tersebut menghasilkan kesepakatan jual beli mobil yang dibuktikan dengan adanya alat bukti pembayaran berupa kwitansi tanpa tempat dan tanggal. Diketahui bahwa perjanjian jual beli antara suami Penggugat dengan Tergugat Zubaidah dilakukan secara lisan Pada kenyataannya objek dalam perjanjian jual beli tersebut merupakan harta bersama antara Penggugat Sainah dengan suaminya H. Muhammad Dasuki.

Perjanjian jual beli yang dibuat oleh suami Penggugat dengan Tergugat Zubaidah tidak diketahui maupun dikehendaki oleh Penggugat Sainah selaku isteri sah dari H. Muhammad Dasuki/suaminya. Karena ketidaktahuan Penggugat sainah akan adanya perjanjian jual beli yang dibuat oleh suaminya dengan Tergugat Zubaidah, Penggugat Sainah mengajukan gugatan terhadap Tergugat Zubaidah, yang mana dasar gugatan dari Penggugat Sainah adalah Perbuatan Melawan Hukum karena Tergugat Zubaidah telah membalik nama BPKB mobil yang merupakan harta bersama dari Penggugat Sainah dengan suaminya menjadi atas nama Tergugat Zubaidah. Dalam petitum Penggugat Sainah memintakan agar mobil tersebut dikembalikan menjadi atas nama Sainah selaku isteri sah dari H. Muhammad Dasuki dan menyatakan bahwa Tergugat Zubaidah telah melakukan Perbuatan Melawan Hukum.

“Amar Putusan Hakim menyatakan menurut hukum bahwa Tergugat telah melakukan Perbuatan Melawan Hukum dan membatalkan kwitansi jual beli tanpa tempat dan tanggal transaksi atas pembayaran satu unit kendaraan roda empat KB. 1435 YL Merk Toyota Warna Silver Metalik, Tipe Model: Mini Bus, Tahun Pembuatan 2008, Nomor Rangka: MHFXW3G184038407 Nomor Mesin: 1 TR-6525894 dengan pertimbangan bahwa balik nama objek sengketa kepada Tergugat tanpa seizin Penggugat adalah Perbuatan Melawan Hukum."

Jika dikaitkan dengan Pasal 1365 KUH Perdata tentang Perbuatan Melawan Hukum yang memiliki pengertian "Melawan hukum adalah sekedar suatu perbuatan yang melanggar hak subyektif orang lain atau yang bertentangan dengan kewajiban hukum dari si pembuat sendiri." 13 Jadi perbuatan tersebut harus melanggar hak subyektif orang lain atau bertentangan dengan kewajiban hukum dari si pembuat sendiri, yang telah diatur dalam undang-undang atau dengan perkataan lain melawan hukum ditafsirkan sebagai melawan undang-undang. Menurut arrest 1919, bahwa berbuat atau tidak berbuat merupakan suatu perbuatan melawan hukum, jika14:

\section{a. Melanggar Hak Orang Lain}

Melanggar hak orang lain adalah melanggar hak subyektif orang lain. Hak subyektif terbagi dua, yang pertama hak perseorangan seperti kebebasan, kehormatan, nama baik, yang kedua hak atas harta kekayaan seperti hak-hak kebendaan dan hak mutlak lainnya.

Pada Kasus Putusan Mahkamah Agung Nomor 1081K/PDT/2018 Tergugat Zubaidah telah melanggar hak kebendaan dari Penggugat Sainah, karena telah membalik nama BPKB mobil menjadi atas nama Tergugat tanpa seizin dari Penggugat Sainah. Maka secara otomatis Tergugat Zubaidah telah melanggar hak orang lain di dalam kasus ini.

b. Bertentangan dengan Kewajiban Hukum Pembuat15

\footnotetext{
Munir Fuady, “Hukum Kontrak (dari sudut pandang hukum bisnis)”, Citra Aditya Bakti, Bandung, 2006, hlm. 4. Abdulkadir Muhammad., "Hukum Perikatan", Alumni, Bandung, 2007, hlm.148

Achmad Ichsan, “Hukum Perdata”, PT. Pembimbing Masa, Jakarta, 2007, hlm. 250.
} 
Kosmik Hukum Vol. 19 No. 2 (2019): 14-23

E-ISSN: 2655-9242 | P-ISSN: 1411-9781

DOI: $10.30595 /$ kosmikhukum.v20i1.6324

Perbuatan Melawan Hukum ditafsirkan bertentangan dengan kewajiban menurut undang-undang, seperti perbuatan-perbuatan pidana, pencurian, penipuan, dan pengrusakan.

Pada dasarnya Tergugat Zubaidah dalam Kasus Putusan Mahkamah Agung Nomor 1081K/PDT/2018 tidak melakukan perbuatan yang bertentangan dengan kewajiban hukum pembuat, karena perjanjian jual beli antara Tergugat Zubaidah dengan suami Penggugat dilakukan sesuai dengan aturan jual beli yang diatur khusus di dalam KUHPerdata. Hanya saja perjanjian jual beli menjadi batal demi hukum karena jual beli dalam konteks harta bersama tersebut tidak diketahui oleh Penggugat selaku isteri sah.

\section{c. Bertentangan dengan Kesusilaan}

Berkaitan dengan norma moral, sepanjang dalam kehidupan masyarakat diakui sebagai norma-norma hukum.16 Di dalam norma masyarakat, perbuatan hukum yang dilakukan terhadap harta bersama tidak mempermasalahkan ada atau tidaknya izin dari isteri maupun suami dalam melakukan perbuatan hukum atas hartanya. Tetapi sudah sepatutnya isteri mengetahui jika suami akan melakukan perbuatan hukum atas harta bersama di dalam perkawinan. Dalam konteks ini Tergugat tidak melakukan perbuatan yang bertentangan dengan kesusilaan karena Tergugat tidak mengetahui bahwasanya mobil tersebut merupakan harta bersama antara Penggugat dengan suaminya.

d. Bertentangan dengan kepatutan yang berlaku dalam lalu lintas masyarakat terhadap diri atau orang lain.

Dapat dianggap bertentangan dengan kepatutan17 adalah : 1) 18Perbuatan yang sangat merugikan orang lain tanpa kepentingan yang layak; 2) Perbuatan yang tidak berguna yang menimbulkan bahaya terhadap orang lain, menurut manusia yang normal hal tersebut harus diperhatikan. Pada Kasus Putusan Mahkamah Agung Nomor 1081K/PDT/2018 perbuatan Tergugat yang membalik nama BPKB mobil milik Penggugat Sainah, sangat merugikan Penggugat Sainah dalam hal menyangkut hak atas harta kekayaan atau hak kebendaan. Maka dari itu Tergugat telah melakukan perbuatan yang melanggar norma kepatutan dalam lalu lintas masyarakat.

Telah dijelaskan bahwa yang termasuk kedalam kategori Perbuatan Melawan Hukum adalah perbuatan yang bertentangan dengan undang-undang, perbuatan yang melanggar hak orang lain, perbuatan yang bertentangan dengan kewajiban hukum pembuat, perbuatan yang bertentangan dengan norma kesusilaan dan norma kepatutan. Namun terdapat unsur-unsur dari perbuatan melawan hukum yang jika tidak terpenuhi salah satunya maka perbuatan tersebut tidak dapat dikategorikan sebagai perbuatan yang melawan hukum.19

Unsur-unsur yang harus dipenuhi agar seseorang dapat dikatakan telah melakukan perbuatan melawan hukum ialah :

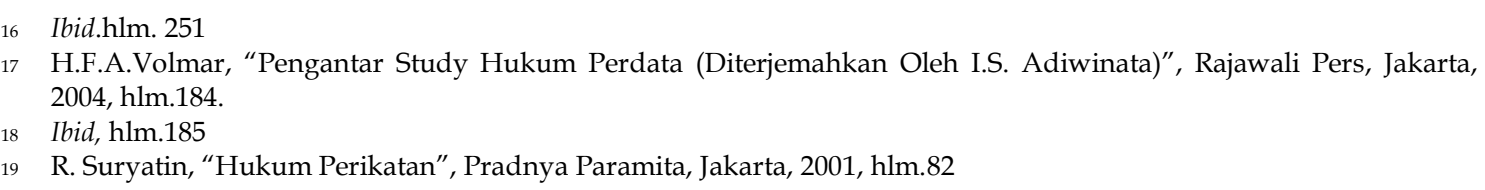




\section{Perbuatan itu harus melawan hukum (Onrechtmatig).20}

Perbuatan yang dilakukan tersebut haruslah melawan hukum. Sejak tahun 1919, unsur melawan hukum tersebut diartikan dalam arti yang seluas-luasnya, yakni meliputi hal-hal sebagai berikut21 :

a. Perbuatan yang melanggar hak orang lain yang dijamin oleh hukum;

b. Perbuatan yang bertentangan dengan kewajiban hukum si pelaku;

c. Perbuatan yang bertentangan dengan kesusilaan (goede zedeen);

d. Perbuatan yang bertentangan dengan sikap yang baik dalam bermasyarakat untuk memperhatikan kepentingan orang lain.

Dari penjelasan tersebut dalam Kasus Putusan Mahkamah Agung Nomor 1081K/PDT/2018 mengenai syarat seseorang dikategorikan telah melakukan perbuatan melawan hukum adalah orang tersebut telah melanggar hak orang lain, melanggar kewajiban hukum si pembuat, melanggar norma di masyarakat dan melanggar norma kepatutan. Maka dapat disimpulkan Tergugat Zubaidah telah memenuhi perbuatan yang melanggar hak orang lain dan melanggar kepatutan dalam lalu lintas masyarakat.

\section{Perbuatan itu harus menimbulkan kerugian.22}

Pada Kasus Putusan Mahkamah Agung Nomor 1081K/PDT/2018 Tergugat Zubaidah telah melanggar hak kebendaan dari Penggugat Sainah, karena telah membalik nama BPKB mobil menjadi atas nama Tergugat tanpa seizin dari Penggugat Sainah. Maka secara otomatis Tergugat Zubaidah telah melanggar hak orang lain di dalam kasus ini dan menyebabkan kerugian pada Penggugat. Kerugian yang dimaksud berupa kerugian materiil berupa 1 (satu) unit kendaraan roda empat B 1435 YL Merk Toyota warna Silver Metalik, Tipe Toyota Kijang Inova, Model Mini Bus tahun pembuatan 2008, Nomor Rangka MHFXW3G184038407 Nomor Mesin 1 TR-6525894.

\section{Perbuatan itu harus dilakukan dengan kesalahan (kelalaian).}

Karena Pasal 1365 KUHPerdata mensyaratkan adanya unsur "kesalahan"(schuld) dalam suatu perbuatan melawan hukum, maka perlu diketahui bagaimana cakupan dari unsur kesalahan tersebut. Suatu tindakan dianggap oleh hukum mengandung unsur kesalahan sehingga dapat dimintakan tanggung jawabnya secara hukum jika memenuhi unsur - unsur sebagai berikut:

\section{a. Ada unsur kesengajaan23}

Sengaja dalam arti kata ini mempunyai makna bahwa perbuatan tersebut dilakukan karena pembuat mengetahui dan menghendaki adanya perbuatan tersebut. Mengetahui disini adalah pembuat mengetahui akan resiko dari perbuatan yang akan dilakukan sedangkan menghendaki adalah pembuat telah mengetahui resiko bila ia melakukan perbuatan tersebut tetapi pembuat tetap menghendaki perbuatan tersebut dilakukan.

Dalam kasus Putusan Mahkamah Agung Nomor 1081K/PDT/2018 Tergugat tidak memenuhi unsur kesengajaan, karena Tergugat dalam membalik nama BPKB mobil menjadi

20 R. Wirjono Prodjodikoro, "Perbuatan Melanggar Hukum”, Sumur, Bandung, 2003, hlm.72.

21 Abdulkadir Muhammad, Op.Cit, hlm. 4.

22 Ibid, hlm.83

23 Abdulkadir Muhammad., Op.Cit, hlm.147. 
Kosmik Hukum Vol. 19 No. 2 (2019): 14-23

E-ISSN: 2655-9242 | P-ISSN: 1411-9781

DOI: 10.30595/kosmikhukum.v20i1.6324

atas namanya tidak mengetahui bahwa sebenarnya mobil yang Tergugat balik nama merupakan harta bersama antara suami Penggugat dengan Penggugat Sainah. Perbuatan hukum terhadap harta bersama sendiri harus seizin istri, jika tidak maka perjanjian jual beli tersebut menjadi batal demi hukum. Sedangkan Tergugat tidak mengetahui bahwa bisa saja perjanjian jual beli yang dibuatnya dengan suami Penggugat menjadi batal demi hukum.

b. Ada unsur kelalaian (negligence, culpa)

Di dalam unsur kelalaian pembuat seharusnya dapat mengira-ngira bahwa perbuatan yang dilakukannya dapat menimbulkan suatu resiko yang akan berdampak kepadanya, tetapi pembuat dalam hal ini tetap melakukan perbuatan yang seharusnya dapat dihindarkannya.24

Di dalam kasus Putusan Mahkamah Agung Nomor 1081K/PDT/2018 Tergugat Zubaidah tidak mengetahui bahwa mobil yang dibelinya merupakan harta bersama antara suami Penggugat dengan Penggugat Sainah. Karena pada saat jual beli mobil dilakukan, suami Penggugat tidak mengungkit tentang harta bersama antara Penggugat Sainah dengan suaminya. Dan Tergugat sudah beritikad baik untuk menanyakan perihal keabsahan mobil tersebut dengan melakukan penyerahan secara langsung untuk menghindari cacat tersembunyi dari mobil yang dibelinya. Penyerahan mobil dilakukan di kantor samsat sekaligus penandatanganan kwitansi jual beli oleh suami Penggugat, dengan sejumlah harga yang harus dibayarkan oleh Tergugat.

Selain itu pada saat peralihan hak milik dilakukan di kantor samsat Tergugat sudah memeriksa BРКB mobil tersebut dan memeriksa keabsahan dari mobil sampai Tergugat mendaftarkan BPKB mobil menjadi atas namanya. Peralihan hak sendiri terjadi pada saat mobil sudah berada di dalam penguasaan Tergugat, yaitu pada saat suami Penggugat menyerahkan mobil tersebut di kantor samsat. Maka dari itu dalam hal ini Tergugat tidak melakukan kelalaian.

\section{Antara perbuatan dan kerugian yang timbul harus ada hubungan kausal.}

Dalam Hukum Perdata ajaran kausalitas terutama mengenai persoalan apakah terdapat hubungan kausal antara perbuatan yang dilakukan dengan kerugian terdapat beberapa teori, yaitu25:

a. Teori Conditio sin qua non dari Von Buri

Teori ini melihat bahwa tiap tiap masalah yang merupakan syarat untuk timbulnya suatu akibat adalah menjadi sebab dari akibat. Kasus Putusan Mahkamah Agung Nomor 1081K/PDT/2018 jika memakai teori ini maka yang sepatutnya dipersalahkan adalah suami dari Penggugat. Karena Penggugat tidak akan mengalami kerugian dan kehilangan hak atas mobilnya jika Tergugat tidak melakukan jual beli dengan suami Penggugat dan mendaftarkan BPKB mobil menjadi atas nama Tergugat. Pendaftaran BPKB mobil tersebut dilakukan karena sudah ada perjanjian jual beli antara Tergugat dengan suami Penggugat, yang pada kenyataannya suami Penggugatlah yang menjual mobil tersebut kepada Tergugat. Maka dalam teori ini yang sepatutnya dipersalahkan adalah suami Penggugat.

24 M. Yahya Harahap., “Segi-Segi Hukum Perjanjian”, Alumni, Bandung, 2002, hlm.42

25 R. Setiawan.," Pokok-Pokok Hukum Perikatan", Putra A Bardin, Bandung: 2000, hlm. 87 
Berdasarkan analisis tersebut diketahui bahwa pada Kasus Putusan Mahkamah Agung Nomor 1081K/PDT/2018 salah satu unsur dari perbuatan melawan hukum tidak terpenuhi, yaitu tidak terpenuhinya unsur kesalahan karena Tergugat dalam membalik nama BPKB mobil menjadi atas namanya tidak mengetahui bahwa sebenarnya mobil yang Tergugat balik nama merupakan harta bersama antara suami Penggugat dengan Penggugat Sainah. Perbuatan hukum terhadap harta bersama sendiri harus seizin istri, jika tidak maka perjanjian jual beli tersebut menjadi batal demi hukum. Sedangkan Tergugat tidak mengetahui bahwa bisa saja perjanjian jual beli yang dibuatnya dengan suami Penggugat menjadi batal demi hukum.

\section{Penutup}

Berdasarkan uraian pembahasan yang terdapat pada identifikasi masalah, peneliti dapat menarik kesimpulan sebagai berikut : Pertama, Keabsahan proses jual beli suami Penggugat Sainah dengan Tergugat Zubaidah dalam putusan Mahkamah Agung Nomor 1081K/PDT/2018 terhadap mobil yang dipersengketakan dikaitkan dengan pasal khusus mengenai ketentuan jual beli dan Pasal 1320 KUH Perdata tentang syarat sahnya perjanjian adalah tidak sah dan batal demi hukum karena suami Penggugat melanggar syarat kecakapan dan juga melanggar syarat kausa yang halal yang terdapat dalam Pasal 1320 KUH Perdata, serta melanggar Pasal 36 ayat (2) Undang-Undang Perkawinan No. 1 Tahun 1974.

Kedua, Putusan Hakim dalam Perkara Putusan Mahkamah Agung Nomor 1081K/PDT/2018 yang menyatakan bahwa Tergugat melakukan Perbuatan Melawan Hukum adalah tidak dapat dibenarkan karena Tergugat tidak memenuhi salah satu unsur perbuatan melawan hukum yaitu unsur kesalahan. Maka dalam perkara ini Tergugat tidak melakukan perbuatan melawan hukum dan Tergugat sebagai pembeli yang beritikad baik sudah sepatutnya dilindungi oleh hukum.

\section{Daftar Pustaka}

A. Qirom Syamsudin Meliala, Pokok-Pokok Hukum Perjanjian Beserta Perkembangannya, Yogyakarta, Liberty, 2010

Abdulkadir Muhammad., Hukum Perikatan, Alumni, Bandung, 2002

Abdulkadir Muhammad., Hukum Perikatan, Alumni, Bandung, 2007

Achmad Ichsan, Hukum Perdata, PT. Pembimbing Masa, Jakarta, 200

Ahmad Miru, Hukum Perjanjian \& Perancangan Perjanjian.,PT. Raja Grafindo Persada : Jakarta, 2008

H.F.A.Volmar, Pengantar Study Hukum Perdata (Diterjemahkan Oleh I.S. Adiwinata), Rajawali Pers, Jakarta, 2004

Kartini Muljadi dan Gunawan Widjaja, Perikatan yang Lahir dari Perjanjian, Rajawali : Jakarta, 2010

M. Yahya Harahap., Segi-Segi Hukum Perjanjian, Alumni, Bandung, 2002

Mochamad Djais, Hukum Harta Kekayaan Dalam Perkawinan", Fakultas Hukum Universitas Diponegoro : Semarang, 2003

Mochamad Djais,Hukum Harta Kekayaan Dalam Perkawinan, Fakultas Hukum Universitas Diponegoro : Semarang, 2003

Muhammad Billah Yudahian, Perjanjian Jual Beli Secara Online Melalui Rekening Bersama Pada Forum Jual Beli Kaskus, Universitas Hasanuddin: Makassar. 
Kosmik Hukum Vol. 19 No. 2 (2019): 14-23

E-ISSN: 2655-9242 | P-ISSN: 1411-9781

DOI: 10.30595/kosmikhukum.v20i1.6324

Munir Fuady, Hukum Kontrak (dari sudut pandang hukum bisnis), Citra Aditya Bakti, Bandung, 2006

R. Setiawan, Pokok-pokok Hukum Perikatan, Bina Cipta, Bandung, 2007

R. Setiawan.,Pokok-Pokok Hukum Perikatan, Putra A Bardin, Bandung : 2000

R. Suryatin, Hukum Perikatan, Pradnya Paramita, Jakarta, 2001

R. Wirjono Prodjodikoro, Perbuatan Melanggar Hukum, Sumur, Bandung, 2003

R.Subekti dan R.Tjitrosudibio. Kitab Undang-undang Hukum Perdata. Jakarta, Pradnya Paramita, Cetakan ke-37. 2006

Subekti dan Tjitrosudibio, Kitab Undang-Undang Hukum Perdata, Jakarta: PT. Pradnya Paramita, 2008 